\title{
EFFECT OF SOWING DATES ON THE YIELD OF SUNFLOWER
}

\author{
Bulbul Ahmed ${ }^{1}$, Mousumi Sultana ${ }^{2}$, Jesmin Zaman 3 , Santos Kumar Paul ${ }^{4}$, Md. Mokhlesur Rahman 5 , \\ Md. Rezaul Islam ${ }^{6}$ and Falguni Majumdar ${ }^{7}$ \\ ${ }^{1}$ Plant Physiology Division, BARI, Joydebpur, Gazipur; ${ }^{2}$ Tuber Research Sub-Center, BARI, Seujgari, Bogra \\ ${ }^{3}$ Department of Agricultural Extension, Khamar Bari, Dhaka; ${ }^{4}$ Agronomy Division, BARI, Joydebpur, Gazipur \\ ${ }^{5}$ Department of Environmental Science, Jahangir Nagor university, Dhaka \\ ${ }^{6}$ Larsen Chemical Industries, Dhaka and; ${ }^{7}$ Department of Agricultural Extension, Khamar Bari, Dhaka
}

Key words: Sowing dates, yield and Sunflower

\begin{abstract}
The experiment was carried out at Agronomy Research field of Bangladesh Agricultural Research Institute (BARI), Joydebpur, Gazipur and Regional Agricultural Research Station, Hathazari, Chittagong to find out optimum sowing date of sunflower during rabi season 2012-13. The sunflower var. BARI Surjomukhi-2 was used. Five sowing dates; 10 November, 20 November, 30 November, 10 December and 20 December were tested. It was revealed that yield and yield attributes of sunflower were significantly influenced by sowing dates. The maximum plant height $(172.13 \mathrm{~cm})$, head diameter (18.33), weight of seed / per head (66 g), 1000- seed weight $(68 \mathrm{~g})$ and yield (2.5 t $\left.\mathrm{ha}^{-1}\right)$ were obtained from 20 November sowing. The lowest yield $\left(1.83 \mathrm{t} \mathrm{ha}^{-1}\right)$ was obtained from 20 December sowing. The 20 November sowing received the higher duration for maturity (127 days), first flowering (57 days) and seed formation (20 days) while 20 December sowing showed shorter duration for maturity, first flowering and seed formation of 119,54 and 14 days respectively. It was concluded that the 20 November sowing would be the optimum time of sowing for achieving maximum yield of sunflower.
\end{abstract}

\section{Introduction}

Sunflower (Helianthus annuus L.) is one of the most important oil crop occupying the fourth place in the world, grown on $22 \mathrm{M}$ ha in the world and producing about 33 million tons of sunflower seeds harvested around the world (FAO, 2009). The sunflower is grown in the southern part of the country in a very limited scale. Though its production is decreased due to increasing the rice area; it has bright future as the cropping intensity increasing day by day. In order to reduce the oil import, it is needed to increase oil seed production in our country. There are evidence that the sowing time has significant effect on the both seed yields and oil contents of sunflower under varying climatic conditions (Johnson and Jellum, 1972). Sowing dates have also been found to greatly influence vegetative (emergence to first flowering time) and reproductive growth stages (flowering to pod maturity time) of crops (Akther et al., 2013). When emergence rate for each sowing date was calculated using a common base temperature they were found to be well correlated with rate of change of day length. Time of sowing determines time of flowering and it has great influence on dry matter accumulation, seed set and seed yield (Sofield, 1977). To increase yield and its stability, it is necessary to take into consideration to determine the optimum sowing date for achieving higher yield of sunflower. 
Ahmed et al.

\section{Materials and Method}

The experiment was conducted at Agronomy research field of Bangladesh Agricultural Research Institute (BARI), Joydebpur, Gazipur and Regional Agricultural Research Station, Hathazari, Chittagong during the period from November 2012 to March 2013. Four sowing dates viz. 20 November, 30 November, 10 December, and 20 December) were included in the study. The experiment was laid out in a RCB design with three replications. The soil was silty clay loam in texture belonging Chhiata series (AEZ-28) of Grey Terrace soil having low organic matter $(0.97 \%)$ and deficient in total nitrogen $(0.056 \%)$, available phosphorus (12 ppm), exchangeable potassium (0.17 meq/100 g soil) and available sulpher (10 ppm). The var. BARI Surjamukhi-2 was used in this experiment. Unit plot size was $5 \mathrm{~m} \times 4.5 \mathrm{~m}$. Seeds of sunflower were sown in line with spacing of $50 \mathrm{~cm} \times 25 \mathrm{~cm}$. The experimental plots were fertilized by $\mathrm{N}_{92} \mathrm{~K}_{75} \mathrm{P}_{40} \mathrm{~S}_{30} \mathrm{Zn}_{4} \mathrm{~B}_{1} \mathrm{Kg} / \mathrm{ha}$ in the form of urea, triple super phosphate, Muriate of potash, Gypsum and Zinc sulphate respectively. Half of Nitrogen and all of the fertilizers were applied at the time of final land preparation. Rest half of nitrogen was applied in two equal splits at 2025 and 40-45 days after sowing (DAS). Weeding, irrigation, earthling up and other intercultural operations were done as and when required. Varying date of growth level, number of plant/

$\mathrm{m}^{2}$, plant height $(\mathrm{cm})$, number of leaf/plant, leaf area/plant, head diameter $(\mathrm{cm})$, no. of seed / head, thousand seed weight $(\mathrm{g})$ and yield data was recorded. Collected data were statistically analyzed by Mstat- $C$ and means were adjudged by LSD test.

\section{Results and Discussion}

\section{Joydebpur}

In Joydebpur from the Figure 1, it was found that at the first deca-day, the highest temperature was higher above $25^{\circ} \mathrm{C}$ and the rainfall was highest $35 \mathrm{~mm}$. There was no rainfall from the 2nd deca-day of November to till 1st deca-day of February. The temperature of that time was also reduced and as a result the plant growth was hampered due to low miosture of the soil. Alter the 2nd deca day of January the temperature was increasing day by day and in the 2nd deca day of february it rainless than $5 \mathrm{~mm}$. During the crop reproductive stages, in the 1st deca-day it was found that the temperature was increasing and in the 2 nd deca day it was found the rainfall was $30 \mathrm{~mm}$. The lowest temperature $\left(10^{\circ} \mathrm{C}\right)$ was found in 1 st deca-day in January and eventually temperature the rainfall also reduced or not found. Notwithstanding during the maturity period at the 2nd deca-day of Apri, l the temperature was rised near to $35^{\circ} \mathrm{C}$ and the rainfall showed the highest. The shape of this function also describes temperature effects on most biological functions, including plant growth and development. The thermal dependence of the apparent reaction rate for selected enzymes may indicate the optimal thermal range for a plant. For crop plants, the thermal kinetic window (TKW) is generally established as a result of thermally induced lipid phase changes, rubisco activity and the starch synthesis pathway in leaves and reproductive organs (Burke, 1990). The identification of TKWs for different species can aid in the interpretation of the differential temperature stress responses for crop growth and development among species (Burke, 1990). 
Effect of Sowing Dates on the Yield of Sunflower

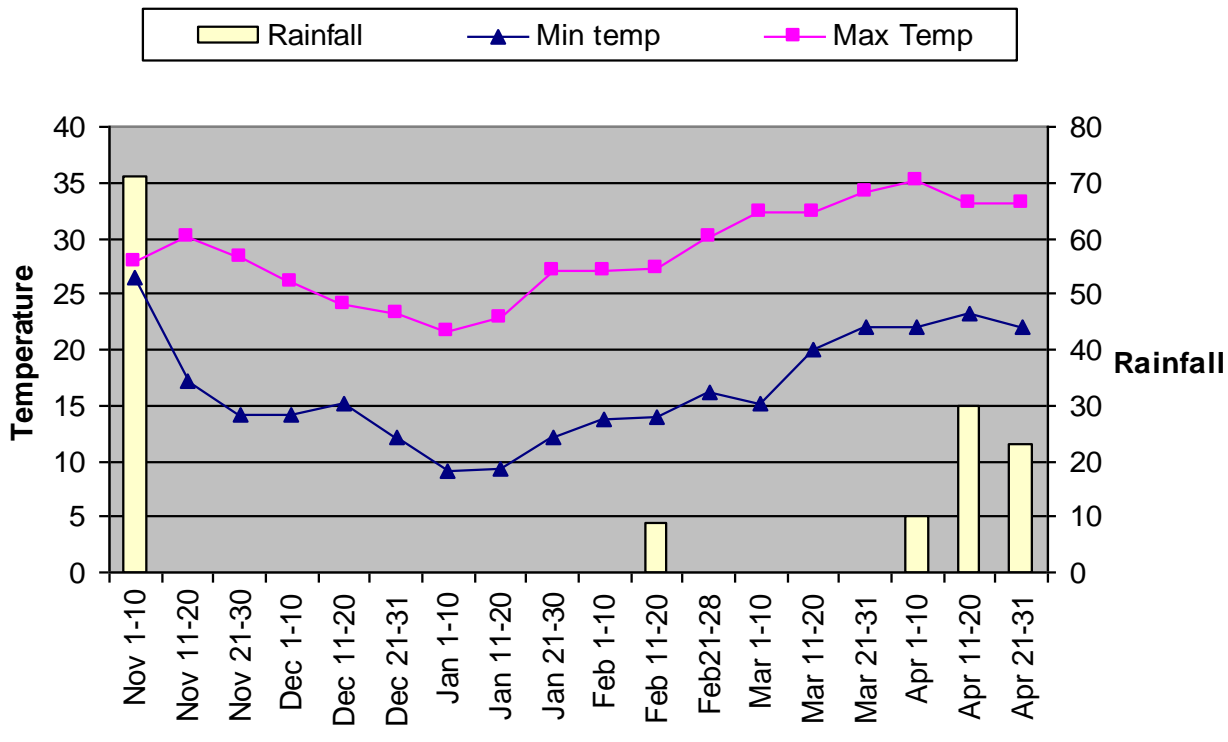

Times

Fig. 1: Deca-day minimum and maximum temperature and rainfall during rabi season of 2012-2013 (Source: BARI Weather Center, 2012-13)

It revealed from the table 1 that sunflower sown at 20 November sowing received the highest time (127 DAS) for maturity while lower at 20 December sowing (119 DAS). For seed formation 20 November sowing took the maximum days (20) whereas 20 December sowing took the minimum days (14). It might be due to the lower temperature from late December to mid January and at this time the vegetative growth was hampered due to low temperature and foggy weather condition. Plants of 20 November sowing took the maximum time (57 days) for first flowering following 30 November sowing (56 days) and 20 December sowing received the minimum 54 days for first flowering. It might be due to increasing temperature from mid February to mid March. To complete the vegetative growth 20 November sowing received the minimum 46 days while the maximum 56 days was found at 20 December sowing. Results revealed that late sown crop flowered earlier than those of early sown crop (Table 1) which might be due to the fact that higher temperature reduced vegetative growth and enhanced flowering (Summer et al., 1985, Nihal 2010). Similar trend was observed in 50\% flowering as well as crop maturity. Late sown crop matured about 7-10 days earlier than that of early sown crop. This was obvious as high temperatures increase rate of plant development (Entz and Fowler, 1991) and reduced length of the reproductive period (Angadi et al., 2000).

Table 1. Effect of sowing dates on the vegetative growth, first flowering, seed formation, and crop duration in Sunflower, Rabi season 2012-13

\begin{tabular}{|c|c|c|c|c|}
\hline Dates of sowing & $\begin{array}{c}\text { Vegetative } \\
\text { growth (Days) }\end{array}$ & $\begin{array}{c}1^{\text {st }} \text { flowering } \\
\text { (Days) }\end{array}$ & $\begin{array}{c}\text { Seed formation } \\
\text { (Days) }\end{array}$ & $\begin{array}{c}\text { Crop growth } \\
\text { duration (Days) }\end{array}$ \\
\hline 10 November & - & - & - & - \\
\hline 20 November & 46 & 57 & 20 & 127 \\
\hline 30 November & 55 & 56 & 14 & 126 \\
\hline 10 December & 55 & 56 & 15 & 123 \\
\hline 20 December & 56 & 54 & 14 & 119 \\
\hline
\end{tabular}


Ahmed et al.

Number of plant $/ \mathrm{m}^{2}$, Plant height, Number of leaf/plant, head diameter, weight of seed per head, thousand of seed weight $(\mathrm{g})$ and seed yields ( $\mathrm{t} \mathrm{ha}{ }^{-1}$ ) were significantly influenced by sowing dates (Table 2) except leaf area, number of seeds / head and plants/ $\mathrm{m}^{2}$. It also revealed that the highest plant height $(172.13 \mathrm{~cm})$ was found in November 20 sowing while the lowest $(166.33 \mathrm{~cm})$ in December 20 sowing. The highest head diameter $(18.33 \mathrm{~cm})$ was found in November 20 sowing while the lowest head diameter $(13 \mathrm{~cm})$ was in December 20 sowing. However, November 20 sowing showed the maximum number of seed/ head (935.33). The maximum weight of seed was found at November 20 sowing $(66 \mathrm{~g})$. The maximum weight of thousand seed was found at November 20 sowing $(68 \mathrm{~g})$ but statistically similar with November 30 sowing $(64 \mathrm{gm})$. The maximum seed yield $\left(2.5 \mathrm{t} \mathrm{ha}^{-1}\right)$ was found with November 20 sowing followed by the November 30 sowing $\left(1.83 \mathrm{t} \mathrm{ha}^{-1}\right)$. Seed yield generally decreased with delayed sowing which might be attributed to the decrease in yield components (Siddique et al., 2002). Reproductive development of many crop species may also be damaged by heat stroke imposing plants produce no flowers or set less number of grains with reduced size.

Table 2. Effect of different sowing dates on the yield and yield attributes of sunflower

\begin{tabular}{l|c|c|c|c|c|c|c|c|c}
\hline Sowing dates & $\begin{array}{c}\text { Plants } \\
/ \mathrm{m}^{2}\end{array}$ & $\begin{array}{c}\text { Plant } \\
\text { height } \\
(\mathrm{cm})\end{array}$ & $\begin{array}{c}\text { Number of } \\
\text { leaf/plant } \\
(1 \mathrm{st} \\
\text { flowering) }\end{array}$ & $\begin{array}{c}\text { Leaf } \\
\text { area } \\
/ \text { plant }\end{array}$ & $\begin{array}{c}\text { Head } \\
\text { Diameter } \\
(\mathrm{cm})\end{array}$ & $\begin{array}{c}\text { No. of } \\
\text { seeds/ } \\
\text { head }\end{array}$ & $\begin{array}{c}\text { Weight of } \\
\text { seeds per } \\
\text { head (g) }\end{array}$ & $\begin{array}{c}1000- \\
\text { seeds } \\
\text { weight } \\
\text { (g) }\end{array}$ & $\begin{array}{c}\text { Seed } \\
\text { yield } \\
\left(\mathrm{t} \mathrm{ha}^{-1}\right)\end{array}$ \\
\hline November 10 & - & - & - & - & - & - & - & - & - \\
November 20 & 5.6 & 172.13 & 23.33 & 259.33 & 18.33 & 935 & 66 & 68 & 2.5 \\
November 30 & 6.0 & 161.26 & 25.66 & 240.33 & 14.33 & 795 & 51 & 64 & 2.0 \\
December 10 & 5.3 & 177.26 & 25.33 & 286.33 & 13.33 & 885 & 50 & 59 & 2.2 \\
December 20 & 5.2 & 166.33 & 20 & 236.33 & 13 & 750 & 50 & 52 & 1.83 \\
\hline LSD $(0.05)$ & 0.85 & 17.85 & 7.80 & NS & 1.6 & NS & 10.29 & 6.87 & 0.56 \\
CV (\%) & 9.75 & 6.84 & 21.47 & 18.46 & 7.06 & 9.54 & 12.33 & 7.36 & 17.17 \\
\hline
\end{tabular}

Table 3. Effect of different sowing dates on the seed yield and yield attributes of sunflower

\begin{tabular}{l|c|c|c|c|c|c|c}
\hline Date of sowing & $\begin{array}{c}\text { Dry } \\
\text { matter } \\
(\mathrm{kg})\end{array}$ & $\begin{array}{c}\text { Plant } \\
\text { height } \\
(\mathrm{cm})\end{array}$ & $\begin{array}{c}\text { Head } \\
\text { size } \\
(\mathrm{cm})\end{array}$ & $\begin{array}{c}\text { No. of filled } \\
\text { seeds/ head }\end{array}$ & $\begin{array}{c}\text { No. of } \\
\text { unfilled seed/ } \\
\text { head }\end{array}$ & $\begin{array}{c}1000- \\
\text { seed wt } \\
(\mathrm{g})\end{array}$ & $\begin{array}{c}\text { Seed } \\
\text { yield } \\
\left(\mathrm{t} \mathrm{ha}^{-1}\right)\end{array}$ \\
\hline November 10 & 0.41 & 137.8 & 16.57 & 125.6 & 440.0 & 82.11 & 0.51 \\
November 20 & 0.56 & 157.0 & 15.30 & 382.7 & 433.8 & 75.10 & 1.16 \\
November 30 & 0.35 & 146.4 & 17.20 & 445.1 & 231.7 & 63.47 & 1.04 \\
December 10 & 0.38 & 145.8 & 14.77 & 405.4 & 263.4 & 62.39 & 0.71 \\
December 20 & 0.43 & 163.1 & 14.60 & 380.0 & 187.4 & 62.27 & 0.76 \\
\hline LSD $(0.05)$ & 0.14 & NS & 16.05 & NS & NS & 13.93 & 0.25 \\
CV (\%) & 18.4 & 6.23 & 16.05 & 23.94 & 24.80 & 10.72 & 16.45 \\
\hline
\end{tabular}

\section{Hathazari, Chittagong}

Significant variation was observed due to varying sowing date in dry matter, head size, thousand seed weight, seed weight /plot, and yield (Table 3). The highest dry matter (0.56 kg), 
plant height $(157 \mathrm{~cm})$ and seed weight per plant $(32.33 \mathrm{~g})$ was found with November 20 sowing while the lowest dry matter $(0.43 \mathrm{~kg})$, plant height $(137.8 \mathrm{~cm})$ and seed weight/ plant $(10.63 \mathrm{~g})$ was found with November 10 sowing. There was no significant identical difference in plant height obtained with November 20 and December 20 sowing. Maximum number of unfilled seed (440.0) was received with November 20 sowing and lowest (187.4) with December 20 sowing. The highest thousand seed weight $(82.11 \mathrm{~g})$ was recorded in November 10 sowing and lowest $(62.27 \mathrm{~g})$ was recorded with December 20 sowing. The highest yield per plot $(2.62 \mathrm{~kg})$ and yield $\left(1.16 \mathrm{t} \mathrm{ha}^{-1}\right)$ was reordered in November 20 sowing, whereas the lowest yield $\left(0.51 \mathrm{~kg} \mathrm{ha}^{-1}\right)$ was recorded in November 10 sowing.

\section{Conclusion}

From the result it revealed that November 20 sowing would be the optimum sowing date for better seed yield of Sunflower.

\section{References}

Angadi, S. V., H. W. Cutforth, P. R Miller, B. G. McConkey, Entz M. H. S. A. Brandt and K.M. Volkmar. 2000. Response of three brassica species to high temperature stress during reproductive growth. Canadian J. Plant Sci. 80: 693-701.

Burke, J.J. 1990. High temperature stress and adaptation in crops. In: Stress Response in Plants: Adaptation and Acclimation Mechanisms. R.G. Alscher and J.R. Cummings (eds.). Wiley, New York. pp. 295-309.

Entz, M. H. and D. B. Fowler. 1991. Agronomic performance of winter versus spring wheat. Agron. J. 83: 527-532.

Nihal, K. 2010. Response of Lentil (Lens culinaris Medik.) to sowing date and timing of nitrogen application. J. Food. Agric. Environ. 8 (2): 422-426.

Jonhson, B. J. and M.D. Jellum. 1972. Effect of planting date on sunflower yield, oil and plant characteristics. Agron J. 64 (6): 747

Siddique, A. B., D. Wright and S.M.M. Ali. (2002). Effect of sowing dateson the phenology, seed yield and yield components of peas. Online Biol. Sci. 2(5):300-303

Sofield, K., L.T Evans, M.G. Cook and F. Wardlaw. 1977. Factors influencing the rate and duration of grain filling in wheat. Aust. J. Plant. Physiol. 4:785-797

Summer, F., R. J., E.H. Roberts, W. Erskine and R. H. Killis. 1985. Effects of temperature and photoperiod and flowering in lentils (Lens culinaris Medic.). Ann. Bot. 56(5): 659-671. 